\title{
Personal Multiple-Text Manuscripts in Late Medieval Central Europe: The 'Library' of Crux of Telč (1434-1504)
}

\begin{abstract}
This study presents the case of the 'library' of a curious late medieval personality: Crux of Telč (1434-1504). During his lifetime, Crux was active in a variety of environments-local schools, university, churches and the Prague chapter, ending up in the Augustinian canonry in Třeboň. Since he was an avid copyist of basically any text he came across, and since he tended to add colophons to his copies, it is possible for researchers to reconstruct his career and his interests. The codices in his 'library' are all multiple-text manuscripts (MTMs), usually of an extremely miscellaneous character. His copies are usually 'creative copies', that is, manuscript versions with a substantial number of unique scribal interventions. The author suggests that Crux's case exemplifies the way in which the boom in information and spread of knowledge in the second half of the fifteenth century were managed.
\end{abstract}

\section{Introduction}

In the Middle Ages, manuscripts were usually kept in institutional libraries (primarily libraries of monasteries or universities) or in personal collections. The former group generally reflects patterns and tendencies of a specific social, cultural or historical situation rather than personal interests, while the latter are usually more limited in time and impact. The example presented here is actually a combination of both: initially, it was a personal library, but it became part of a monastic library later on. Thus, it both reflects personal interests and goes beyond a restricted circle of personal friends and family members in terms of its impact.

The person behind this collection was Crux de Telcz (Kř̌iž of Telč, 1434-1504), a well-known figure among Czech medievalists, partly because he copied a great

The research leading to this study was supported by the Czech Science Foundation through the project 'Creative Copying: Miscellanies of Ulricus Crux de Telcz (d. 1504)', no. 17-06326S, which was carried out at the Faculty of Humanities, Charles University, Prague. I am very grateful to my colleagues Michal Dragoun and Adéla Ebersonová for their kind help (not to mention the editors of this volume). 
number of precious texts written in Old Czech that would otherwise have been lost to posterity. ${ }^{1}$ As we know from the colophons of his manuscript copies, Crux travelled across the region and held various offices. He was active in a variety of environments: in local schools (in Telč, Ždâr, Soběslav, Roudnice nad Labem, Ústí nad Labem and Vyšehrad), at Prague University (from 1459), then at local churches (Plzeň, Nepomuk, Soběslav), St Vitus Cathedral in Prague, and at a canonry. He was ordained in 1463 and entered the Augustinian canonry in Třeboň (Wittingau in German) ${ }^{2}$ in 1478. Crux was an active writer and copyist for at least 48 years: the first note he is known to have written is from Telč in $1454,{ }^{3}$ while the last one is the table of contents he added to MS Prague, National Library of the Czech Republic (hereafter 'NL'), XI C 1 in 1502 in Třeboň (Fig. 1). ${ }^{4}$ When he died on 25 March 1504, almost 50 codices with miscellaneous contents gathered and largely copied by him or containing his additions and corrections remained in the Třeboň library. Selected individual texts and their manuscript transmission have been analysed before, ${ }^{5}$ but there has not yet been any systematic study of Crux's activity as a copyist, translator, author and compiler of multiple-text manuscripts (MTMs); the most detailed contribution to have been made so far is still Kadlec's overview from $1956,{ }^{6}$ but this contains a number of mistakes. Although much more research needs to be carried out before any final conclusions can be made and the following are merely preliminary observations, several patterns have nonetheless emerged that seem to be relevant not only for this particular figure and Bohemia, but also for late medieval manuscript culture in general.

1 Cf. Kopecký (ed.) 1983 and Lehár (ed.) 1990 on medieval Czech literature, among others.

2 The canonry was founded in 1367 by the Rožmberk (Rosenberg) family as the daughter of the canonry in Roudnice nad Labem (Raudnitz).

3 MS Třeboň, State Regional Archives (hereafter SRA) A 7, fol. 74v - the end of a curious opuscule, the so-called Letter of John the Priest. (For a basic description of this codex, see Weber 1958, 63-94.)

4 For a basic codex description, see the catalogue by Truhlář (1906, 129-31). This and all the other manuscripts from the National Library in Prague that are referred to here (except I G 40) are now digitised and freely accessible through www.manuscriptorium.com (last accessed on 17 January 2019). The online foliation sometimes differs slightly.

5 E.g. Kiss 2012 or Coufal 2015.

6 Kadlec 1956. Although Crux is usually called Oldřich Kř̌ž (Ulricus or Udalricus Crux) in secondary sources, there does not seem to be any evidence for the first name. Crux himself never used Ulricus or Udalricus when referring to himself, nor does the the first name appear in the reference to him in the canonry necrologium. In my opinion, the mistake arose most probably already in the eighteenth century: chroniclers of Třeboň overlooked a coma which was separating the names of two canons, Ulricus and Crux de Telcz, in a confraternity contract from 1492. 


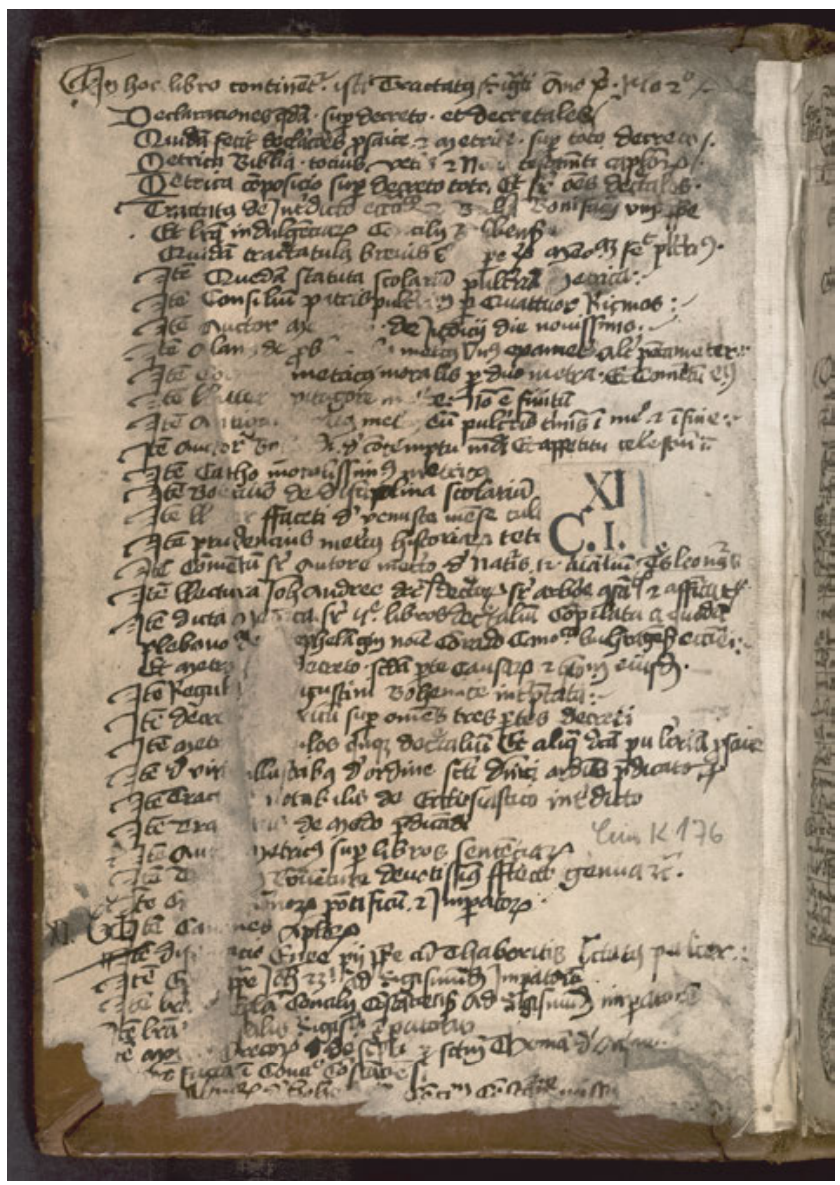

Fig. 1: Prague, NL, XI C 1, inside front cover-a table of contents written by Crux in 1502-the last known sample of his writing.

\section{Crux's codices}

The codices that Crux collected are mostly thick volumes in Latin and Czech with extremely varied contents. Some of his copies still have their original binding, either in undecorated leather or with blind decoration, but it is not clear exactly when they were bound-in some cases, parts of them were obviously originally transmitted as independent booklets. Other codices of his were rebound in the modern era 
when, it seems, the composition of some of them may also have been changed. ${ }^{7}$ Judging from the manuscripts' contents, Crux's interests were very broad: he copied a great deal of theological, moral and devotional literature-biblical commentaries, concordances and expositions, sermons, apocrypha, patristic writings, treatises on particular topics such as sacraments, Church law, morals, explanations (of the Lord's Prayer, for instance), plus confessions, liturgy, homiletics, preachers' handbooks and suchlike. In addition, he copied literary texts (Czech and Latin songs and poems, both contemporary compositions and writings by classical authors), texts for use by his students (Latin-Czech glossaries and grammatical and rhetorical treatises) as well as advanced scientific texts (especially on philosophy, but also on astronomy, medicine and law). Above all, he seems to have been interested in writings that his contemporaries produced. Being active in the second half of the fifteenth century when Bohemia was shaken by religious conflict, many of the writings he copied concern the Hussite movement and other religious movements of the fourteenth and fifteenth centuries (e.g. the writings of Jan Hus, Stanislaus of Znojmo, Štěpán Páleč or Šimon of Tišnov). These include religious polemics, treatises on communion sub una and sub utraque specie, materials from the Council of Constance, and canon law, but also span religious songs and satires as well. One of Crux's codices, Prague, NL, I F 18, is dedicated exclusively to gathering texts pertaining to the religious controversy, but many more such texts are scattered in other volumes of his. His 'library' of writings on late medieval religious polemic in Bohemia is huge-nearly exhaustive, in fact. ${ }^{8}$

It is not very easy to define the group of Crux's codices exactly and argue that they should be perceived as his 'library'; although his hand can be identified with a high level of certainty, the surviving codices vary in the degree of Crux's intervention. It is possible to distinguish two basic groups: 1) codices in which Crux only wrote notes or added tables of contents, and 2) codices partly or completely copied by him.

So far, we know of fourteen codices in the first group, all of which were once owned by the Augustinian canons in Třeboň. Only four of them were known to previous scholarship; all the others were identified during recent work on a catalogue of the medieval library of the canonry. ${ }^{9}$ It is very likely that further research will

7 There are three volumes now, for example: I G 11a, I G 11b and I G 11c, which originally formed a single codex (cf. Truhlář 1905-1906, I, 285-88).

8 František Mareš stated that it is the largest surviving medieval library on the topic. Cf. Mareš 1896, 537.

9 After the canonry was definitively abolished in 1785 during the reforms of Joseph II, most of the codices ended up in the National Library in Prague. Several of them remained in Třeboň, however, and are now kept in the SRA in Třeboň. A small number of them are kept elsewhere: in the Library of the National Museum in Prague, in the Archives of Prague Castle, in the Library of the Strahov 
reveal even more codices in this group. The known manuscripts include ones that Crux may have found in the Třeboň library and manuscripts he brought with him from elsewhere.

The fact that Crux's interventions have only been found in Třeboň codices so far may simply be due to them only being searched for in that particular collection. Even codices he took with him to Třeboň could have been misplaced later, as the canonry escaped the fate of many other places and survived the Hussite wars, but its library was included in that of the Rosenbergs in $1566 .{ }^{10}$ The canonry was reestablished after 1631 and the codices were returned, but it seems that they got mixed up with codices originally owned by the Rosenbergs, so not exactly the same group of codices was returned. There are many volumes that are linked to the Třeboň canonry by a note of ownership from 1718, but it cannot be confirmed that they were kept there before that, during the Middle Ages or thereafter. Earlier studies distinguish between codices originally kept by the canonry and the Rosenbergs, but never explain the method applied in making the distinction. ${ }^{11}$ In any case, the division has often been shown to be wrong, and it seems the two collections did indeed get mixed up. MS Prague, NL, I E 42, for example, which was classified as originally belonging to the Rosenbergs, has a note in it written by Crux de Telcz and it is thus much more likely to have been owned by the canonry. ${ }^{12}$ Although some of the codices include a table of contents that Crux added, the degree of his intervention in these works is generally very low and there is usually no indication he considered them his own property either. On the contrary, some are explicitly presented by Crux as not being his: MS Prague, NL, I F 35, for example, is a MTM written by Mattheus Beran, an Augustinian canon from Roudnice nad Labem, from 1421 to

Monastery in Prague, in the Library of the Knights of the Cross with the Red Star in Prague, and even abroad - one codex is in the Vatican Library, one in Klosterneuburg and one in Wrocław (Breslau). Altogether, there are over 300 extant medieval codices from the medieval library of the Augustinian canons in Třeboň. The stock of the Třeboň library seems to have been mixed together with the holdings of a nearby Augustinian canonry in Borovany, from which almost 60 codices have survived. In a number of cases, it is now impossible to say which of the canonries kept them. A catalogue of the codices held by both these canonries is currently being prepared by Michal Dragoun and Adéla Ebersonová.

10 Many of the codices contain the chalcographic ex libris of Petr Vok of Rožmberk from 1609. During the Thirty Years War (1618-1648), many volumes from the Rosenberg library were seized as booty (and may still be found in certain Swedish libraries today; no codices that are clearly from the Třeboň canonry have been identified in Sweden yet, but there may be some).

11 Kadlec 2004, 130-31.

12 This manuscript is one with little intervention by Crux: he only added a title to one text, $D e$ veneno infectis (fol. 78r). This note was discovered by Michal Dragoun. 
1431 while he was in Erfurt. ${ }^{13}$ It contains a number of notes by Crux, who also manifestly used it as a model for his own copies of several texts. The codex ended up in the Třeboň library, but it is not clear if Crux found it there or he actually brought it to Třeboň himself. Whatever the case, even when stored in Třeboň, it was regarded as the property of Roudnice-Crux even added a note to this effect: 'Rudnicensium liber est, non noster' ('The book belongs to [the canons] of Roudnice, not to us'; fol. 1r). In Prague, NL, I G 40, the table of contents that Crux added on the front inside cover begins with the words 'Iste liber est monasterii Trzebonensis, et continentur ista in eo' ('This book belongs to the monastery of Třeboň and these [works] are included in it'). This suggests that Crux's 'library' is indeed a sort of construction.

As for the codices that were partly or completely copied by Crux, 32 such volumes have been identified so far plus two adligata and a fragment of 10 folios. This number is less likely to grow than the number of codices from the previous group, as Crux's handwriting is quite distinctive and would probably have already been noticed in Czech libraries. However, there may be some relevant codices abroad that have gone unnoticed.

In the case of eight of these volumes, Crux only copied a small part of them (no more than 10 per cent of the codex), in 22 of them he wrote about half of each codex, and in two other instances, he copied them almost completely. These numbers should be dealt with carefully, however-it is clear that many parts of the codices were originally transmitted individually and only bound together later, so during much of Crux's lifetime, the 'units' may actually have looked quite different (and thus the proportion of his own copies to those acquired in other ways may have been different, too). Most of the codices are composed of what were separate parts originally, written at various times and often in various places and by different hands. Several of them were probably bound in Třeboň at roughly the same time, though. ${ }^{14}$ In addition, the composition of some of the codices may have been changed when they were rebound in modern times. Sometimes incunables have been bound together with manuscripts. In a number of these cases, there is evidence that the manuscript accompanied the particular incunable before the binding; Prague, NL, 44 D 4, for example, contains a print of Jacobus de Voragine's

13 A digital copy is available through Manuscriptorium; for a full description, see Dragoun / Ebersonová 2015, 498-502.

14 There is a group of codices from Třebon̆ that share the stamps of the blind decoration on their leather covers, but only some of them bear traces of Crux's activity, so he cannot be made responsible for arranging the binding. In the Einbanddatenbank (http://www.hist-einband.de/), this binding workshop is named after one stamp, Kruzifixus (its identifier, or 'Werkstatt Zitiernummer', is w000127), and it is associated with Třeboň 1473-1500. 
Legenda aurea (Ulm: Johann Zainer, 1477) ${ }^{15}$ followed by seven manuscript folios. The incunable contains a number of notes in Crux's hand and there are several inserted and bound-in smaller leaves with further legends as well. ${ }^{16}$ The manuscript bound to it contains a text of the same genre-a fragment of Rufinus of Aquileia's Vitas patrum. ${ }^{17}$ The fact that Crux perceived his manuscript copy as a continuation of the print is clear from its foliation-the foliation he added to it continues the foliation of the print (i.e. 421-427, at the top of the pages, in Roman numerals). This is not an isolated case; in fact, it shows clearly that when studying late medieval written culture, it is necessary to consider manuscripts and prints together, which is the way they were transmitted and read originally.

The codices also differ in the amount of information they provide on Crux's copying. He often (but not always) added colophons to his copies, specifying the place where they had been written, the time and other details. So far, we have discovered over 130 of his colophons. His strategy varied, however: sometimes he only wrote down the place where the work had been copied, on other occasions he only noted the date (either the full date or just the year), and in other cases he specified what role he had at the institution or even which exemplar he was copying from. There are manuscripts with colophons of this type after almost every text and others without any explicit indication that it was Crux who had copied the text. Besides commenting on his own copies, he often mentioned the ways in which he acquired other copies, too. In addition to the colophons, some of Crux's marginal notes are of a personal character; thanks to those, we have the aforementioned information on his birth, for example, or on a conflict he experienced while teaching at Vyšehrad in November $1457 . .^{18}$ Such personal notes are very rare, though-Crux wrote a great number of marginal and interlinear glosses, but as a rule, they comment on and explain the main text, regardless of whether it is his own copy (Fig. 2) or someone else's (Fig. 3).

15 ISTC: ij00088400.

16 E.g. fol. 25 bis $r-v$ has a legend on John the Apostle.

17 Originally, there were at least 15 manuscript folios, and their remains are still visible. On the back cover, Crux listed the original contents of the volume, most of which have not been preserved.

18 MS Prague, NL, I F 25, fol. 103r (but referred to as $104 \mathrm{r}$ in Manuscriptorium). 


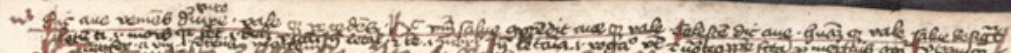

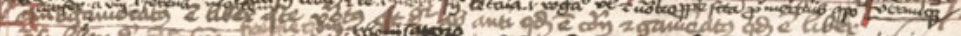

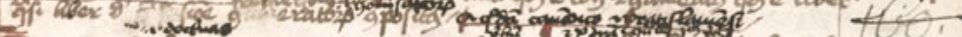

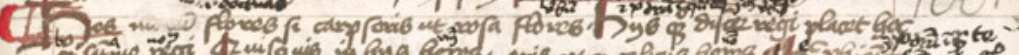

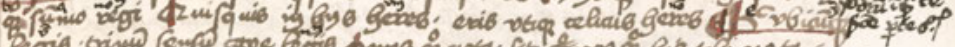

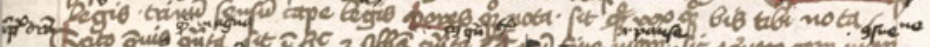

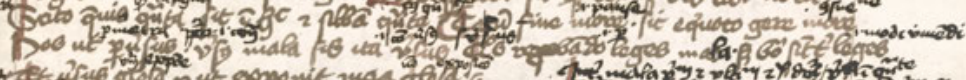
prab

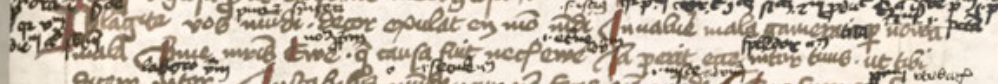

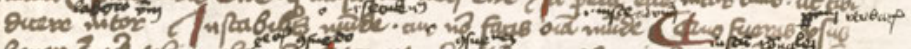

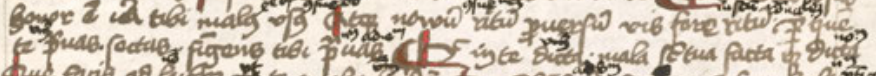

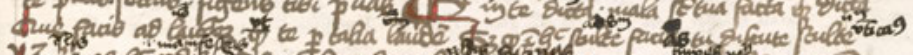

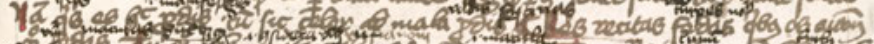

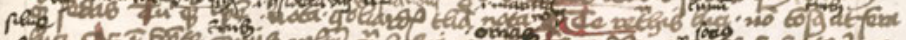

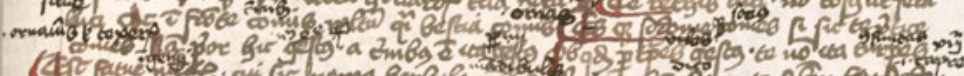

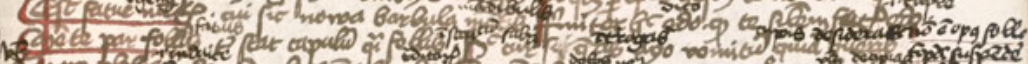

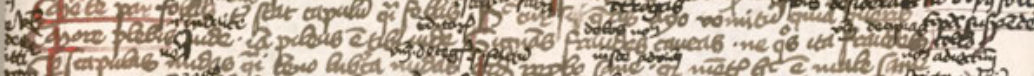

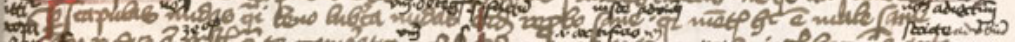

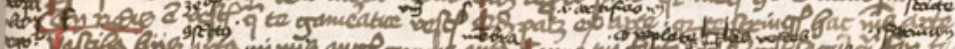

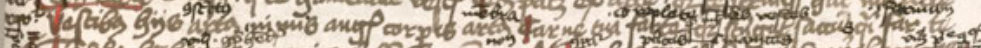

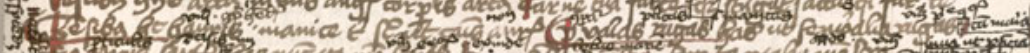

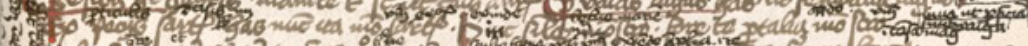

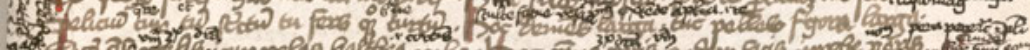

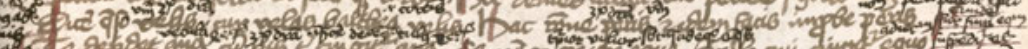

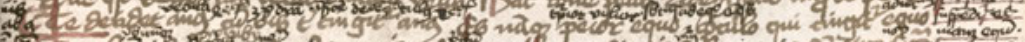

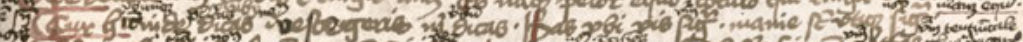

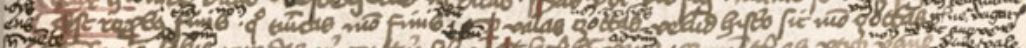

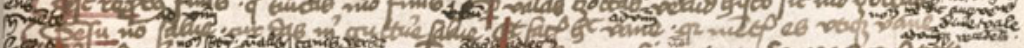

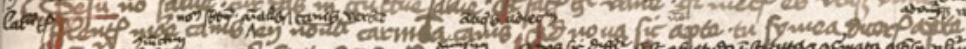

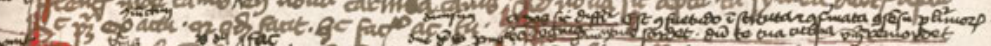

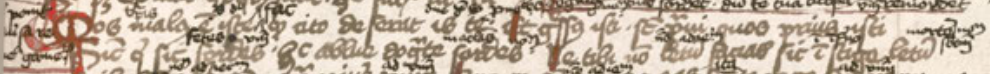

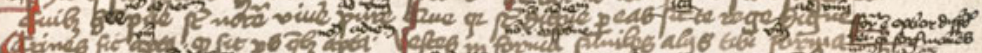

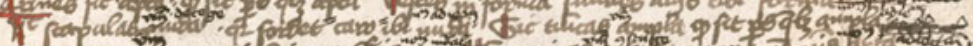

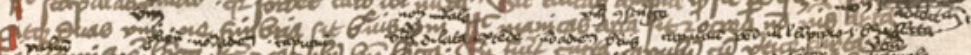

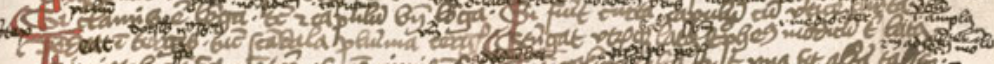

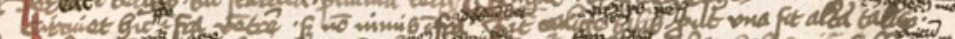

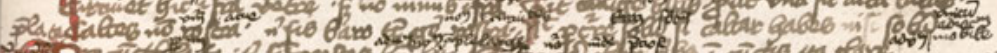

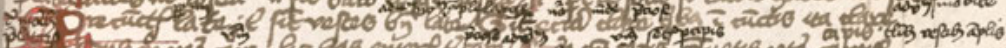

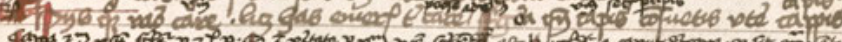

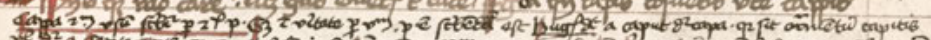

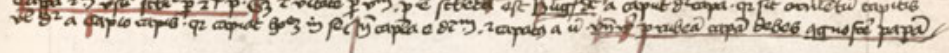

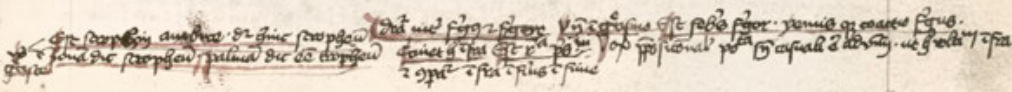

Fig. 2: Prague, NL, XI C 1, fol. 187r-example of Crux's notes added to his own copy (here Frowinus of (racow's Antigameratus). 


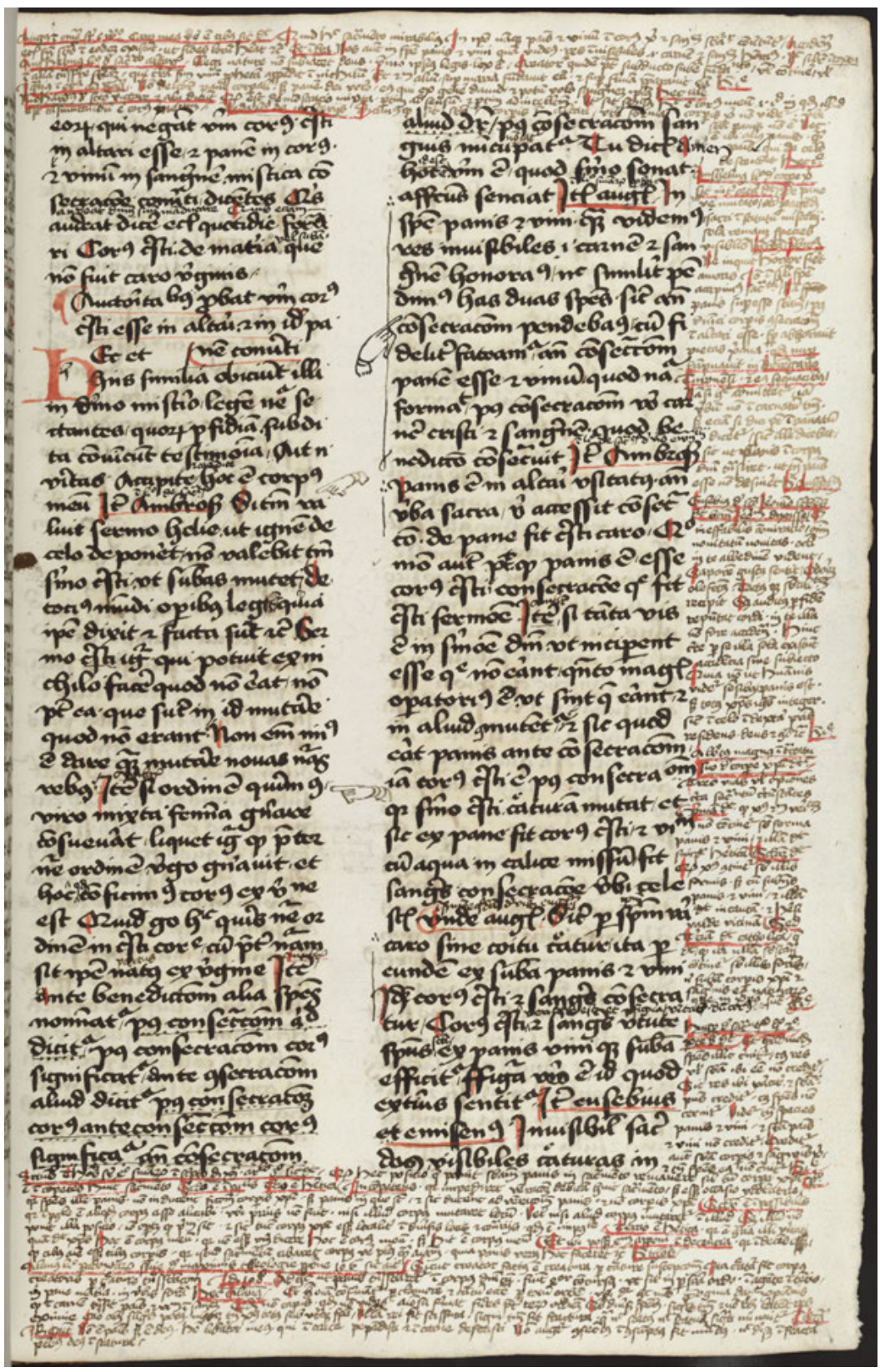

Fig. 3: Prague, NL, I C 16, fol. 209r-example of Crux's notes added to a different scribe's copy (here Peter Lombard's Sentences copied by Vavřinec of Znojmo-Laurinus de Znoima in 1465; this page is more heavily commented on than the others). 


\section{Crux's library?}

Crux did not sign his own codices beyond adding the colophons, nor are there any other signs, such as ex libris, that show he considered them part of a library at all or that he kept this library separate from the other books in the canonry. Were these codices really part of Crux's own library? One of them, Prague, NL, I B 33, written mostly between 1377 and 1384 and primarily containing a postil by Conrad Waldhauser, has a note in Crux's hand stating that he had bought it himself (Fig. 4):

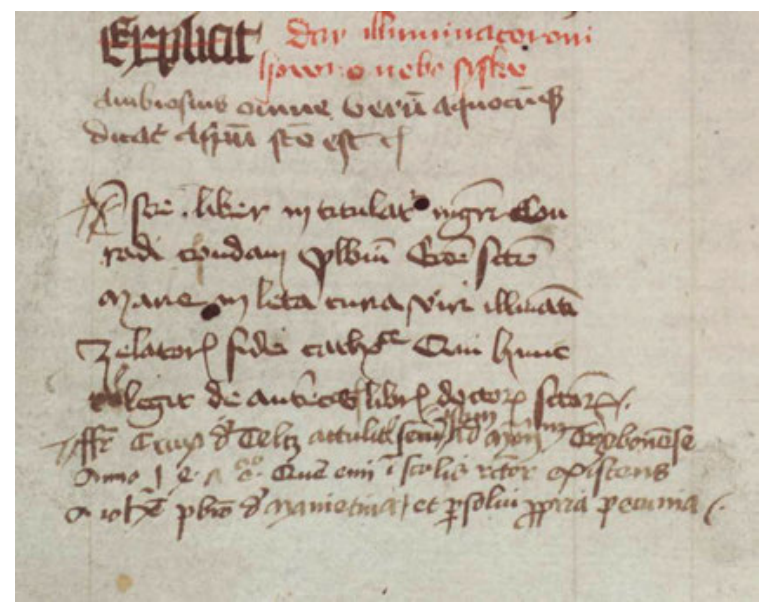

Fig. 4: Prague, NL, I B 33, fol. 256v-Crux's note on purchasing a codex.

Frater Crux de Telcz attulit secum ad monasterium Trzeboniense anno 1478 quem emi in scolis rector existens a Johanne presbytero de Manietina et persolvi propria pecunia (fol. 256v). ${ }^{19}$

Brother Crux de Telč brought [this book] with him to the Třeboň Monastery in 1478, which I bought from John, a priest from Manětín, ${ }^{20}$ while I was a headmaster and which I paid for with my own money.

19 Above Crux's own note, there are three other notes by three other hands. The most curious remark is the first one, in red, which is in Czech: 'Daj illuminatorovi hovno nebo šišku' (literally, 'Give to the illuminator shit or cone').

20 A small town around 30 km north-west of Plzeň (Pilsen). 
The note moves from the third person singular to the first person singular when referring to Crux. It also seems to put some emphasis on the fact that Crux paid for the book with his own money ('persolvi propria pecunia'). He says he brought it with him to Třeboň ('attulit secum'), but he does not explicitly state that he gave it to the Třeboň Monastery. On the other hand, giving up his own property to the canonry might have seemed an obvious thing to do - it is clearly stated in the statutes of Roudnice, which were valid in Třeboň, too, that canons were not allowed to have any personal property. The oath that novices took upon entering the institution is very clear about this: 'Promitto deo et vobis obedienciam et stabilitatem sine omni proprietate...' ('I promise obedience and stability to God and to you without any property...'). In addition, there is a special chapter in the statutes entitled Quid frater suum dicere debeat ('What the brother should call "his"'), which states that the brothers could only use the word 'mine' when referring to their guilt or their parents. ${ }^{21}$

Thus, a note of personal ownership may not have been an option at all in this context. In fact, several codices have an explicit note in Crux's hand that they belong to the Třeboň canonry. This is the case for MS Třeboň, SRA, A 13, for instance, where Crux added the following words inside the front cover:

Liber monasterii Trebonensis. Tituli libri huius signati sunt per me fratrem de Telcz, ut facilius materia et cicius secundum ordinem posicionis libri [inveniri possit?]

Book of the Třeboň Monastery. The titles of this book have been designated by me, [a] brother from Telč, so that the matter [could be found] more easily and faster according to the order of the position within the book.

The only possibility of 'personalisation' might have been adding marginal notes, which is exactly what Crux did. Besides inserting numerous notes of this kind, he used maniculae ('little hands' in the margins to highlight an important passage) very frequently. These are quite distinct, just like his handwriting. Sometimes, there are even clusters of them, as in Prague, NL, I F 25, fol. 302v (Fig. 5).

There are several codices which he started before entering the canonry and only finished there several decades later. One such example is Prague, NL, I E 38.

21 'Nihil frater "suum" appellet singulariter sed ad omnia "nostrum" nisi de culpis de patre aut matre. De hiis solis dicat licenter "meus" et "mea"' ('The brother is not to call anything individual "his", but is to refer to everything as "ours", except [when he speaks] about guilt [or] about [his] father and mother. Only concerning these things is he allowed to say "my”'). Cf. Ebersonová / Klímová 2015 and Ebersonová 2019. 
Fig. 5: Prague, NL, I F 25, fol. 302v - an example of clusters of maniculae by Crux.

Crux copied Jean Versor's commentary on Aristotle in it in Prague, where he stayed at the college of King Wenceslas ${ }^{22}$ in 1459 during his university studies. He added an index to it in 1495 (fols 365v-370v) in the canonry in Třeboň. ${ }^{23}$ Similarly, MS Prague, NL, I F 25 was written in Soběslav in 1455, in Vyšehrad in 1458 and in Prague in 1459, again at the college of King Wenceslas. The 1459 part contains Jean Versor's commentary on Metaphysics, which Crux copied soon after finishing I E 38. ${ }^{24}$ Crux also added final indices to this manuscript in Třeboň in 1495. In fact, he wrote the indices for Versor in both codices almost at the same time: one in I E 38 on 28 July (fol. 370v) and the two in I F 25 on 30 and 31 July (fols 304v and 307v respectively). The fact that Crux intervened in codices he had copied himself years after entering the canonry suggests he might have kept them or have had 'his own shelf' in the library.

22 Prague University had several colleges. King Wenceslas College was founded before 1381; cf. Šmahel 2007.

23 Fol. 370v: 'Finis titulorum et quescionum Johannis Versoris super libros Aristotilis naturalis philosophie et parvorum naturalium per me fratrem Crucem de Telcz in monasterio Trzebonensi sub abbate Marco, priore Johanne de Tisnow, anno Domini 1495 in die Panthaleonis in vigilia Marthe [28.7.1495]. De iuventute et senectute, De inspiracione et respiracione, De vita et morte, De motu animalium, De motu cordis - istos tractatus quinque parvorum naturalium Aristotilis non habeo in hiis quescionibus Versoris'. ('The end of the titles and questions of Jean Versor on Aristotle's books of natural philosophy and short treatises on nature by me, brother Crux of Telč, in the Třeboň Monastery under Abbot Mark, Prior John of Tišnov, in the year 1495, on the day of St Pantaleon, the eve of St Martha. On youth and old age, On inspiration and respiration, On life and death, On the movement of animals, On the movement of the heart - I do not have these five short treatises on nature by Aristotle among these questions by Versor'.)

24 The last colophon in I E 38 is from 1 August 1459; the relevant colophon here, on fol. 128v, is from 29 November (the 128 folios are covered with the commentary on Metaphysics). 


\section{Crux's copies}

Crux's copy of Versor's commentaries in I E 38 is also special because its colophons (all of which are included in the Appendix to this paper) are more numerous than usual: there are 15 entries from 1459, one from 1495, and a (so far overlooked) note stating Crux was born on 24 December 1434 (fol. 264r, Fig. 6). ${ }^{25}$

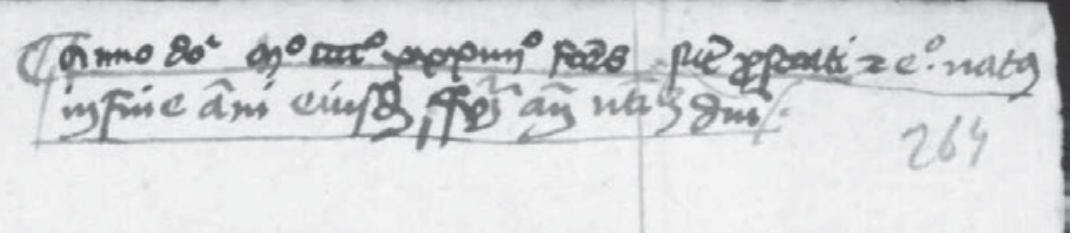

Fig. 6: Prague, NL, I E 38, fol. 264r-a note on the birth of Crux on 24 December 1434.

The manuscript shows that his copying activity was quite intensive between April and July 1459 , although his daily output varied considerably:

\begin{tabular}{rrrrr}
\hline Segment & No. of days & Foliation & Folios copied & $\begin{array}{r}\text { Average no. of folios } \\
\text { copied per day }\end{array}$ \\
\hline 1 & 3 & $83 r-95 r$ & 12 & 4 \\
2 & 8 & $95 \mathrm{r}-119 \mathrm{r}$ & 24 & 3 \\
3 & 3 & $119 \mathrm{r}-141 \mathrm{r}$ & 22 & 7.3 \\
4 & 19 & $141 \mathrm{r}-194 \mathrm{v}$ & 53 & 2.8 \\
5 & 11 & $194 \mathrm{v}-227 \mathrm{v}$ & 33 & 3 \\
6 & 8 & $227 \mathrm{v}-246 \mathrm{v}$ & 19 & 2.4 \\
7 & 4 & $246 \mathrm{v}-256 \mathrm{v}$ & 10 & 2.5 \\
8 & 0 & $256 \mathrm{v}-264 \mathrm{r}$ & 7 & 7.0 \\
9 & 3 & $264 \mathrm{r}-269 \mathrm{bis} \mathrm{r}$ & 6 & 2.0 \\
10 & 21 & $269 \mathrm{bis} \mathrm{r}-313 \mathrm{v}$ & 44 & 2.1 \\
\hline
\end{tabular}

25 'Anno domini 1434 fratres sunt prostrati et ego natus in fine anni eiusdem feria sexta ante nativitatem domini'. ('In the year of Our Lord 1434, brothers were overthrown and I was born at the end of that year on Friday before the Birth of the Lord'.) The conflict referred to is the battle of Lipany (30 April 1434), a crucial event where the Orphans and Taborites (the extremist Hussites) were defeated by the moderate Hussites. 


\begin{tabular}{rrrrr}
\hline Segment & No. of days & Foliation & Folios copied & $\begin{array}{r}\text { Average no. of folios } \\
\text { copied per day }\end{array}$ \\
\hline 11 & 4 & $313 v-333 r$ & 19 & 4.8 \\
12 & 5 & $333 r-350 v$ & 18 & 3.6 \\
13 & 2 & $350 v-355 r$ & 5 & 2.5 \\
14 & 4 & $355 r-365 r$ & 10 & 2.5 \\
\hline
\end{tabular}

The average for the whole period is three folios per day, which corresponds to the fact that Crux was not a professional scribe but a student who had other activities to do besides copying. An intensive copying period (segment 3 ) is followed by a more relaxed one (segment 4), but together, they make an average close to the general one. 23 June is curious, as it has two colophons (segment 7 and 8), the second one six folios after the first one, adding that the copying was finished at the 22nd hour of the same day.

The colophons themselves seem to promote the scribe more than the author, even in terms of their shape. Most notably, the final one on fol. 365r uses much bigger letters to inform about Crux, the copyist, than those identifying the author of the text (Fig. 7):

And this is the end of the exposition of the Philosopher's books of natural philosophy edited in the form of questions by Master John, called Versor, at Paris University, and brought here by Master Václav of Vrbno, at that time a bachelor, finished by Kř̌ž of Telč, a student at the college of King Wenceslas, on Wednesday of the feast of the liberation of St Peter, in 1459 $[1.8 .1459]{ }^{26}$

As the colophon explains, Jean Versor's commentaries came to Prague through Václav z Vrbna (Wenceslas de Wrbna). Václav studied in Paris and brought the first of them to Prague in 1445. They became very popular, so he returned to Paris in 1450 to copy more of them. The Czech copies are numerous (Jean Versor was actually more widely disseminated in Prague than in Paris) and they were made quite early-25 of the 31 surviving manuscripts were copied between 1455 and $1460 .{ }^{27}$ All in all, the manuscript tradition reinforces the suggestion that Crux was primarily interested in new, contemporary texts.

26 For the Latin text, see the last item in the Appendix.

27 Šmahel 1980. 


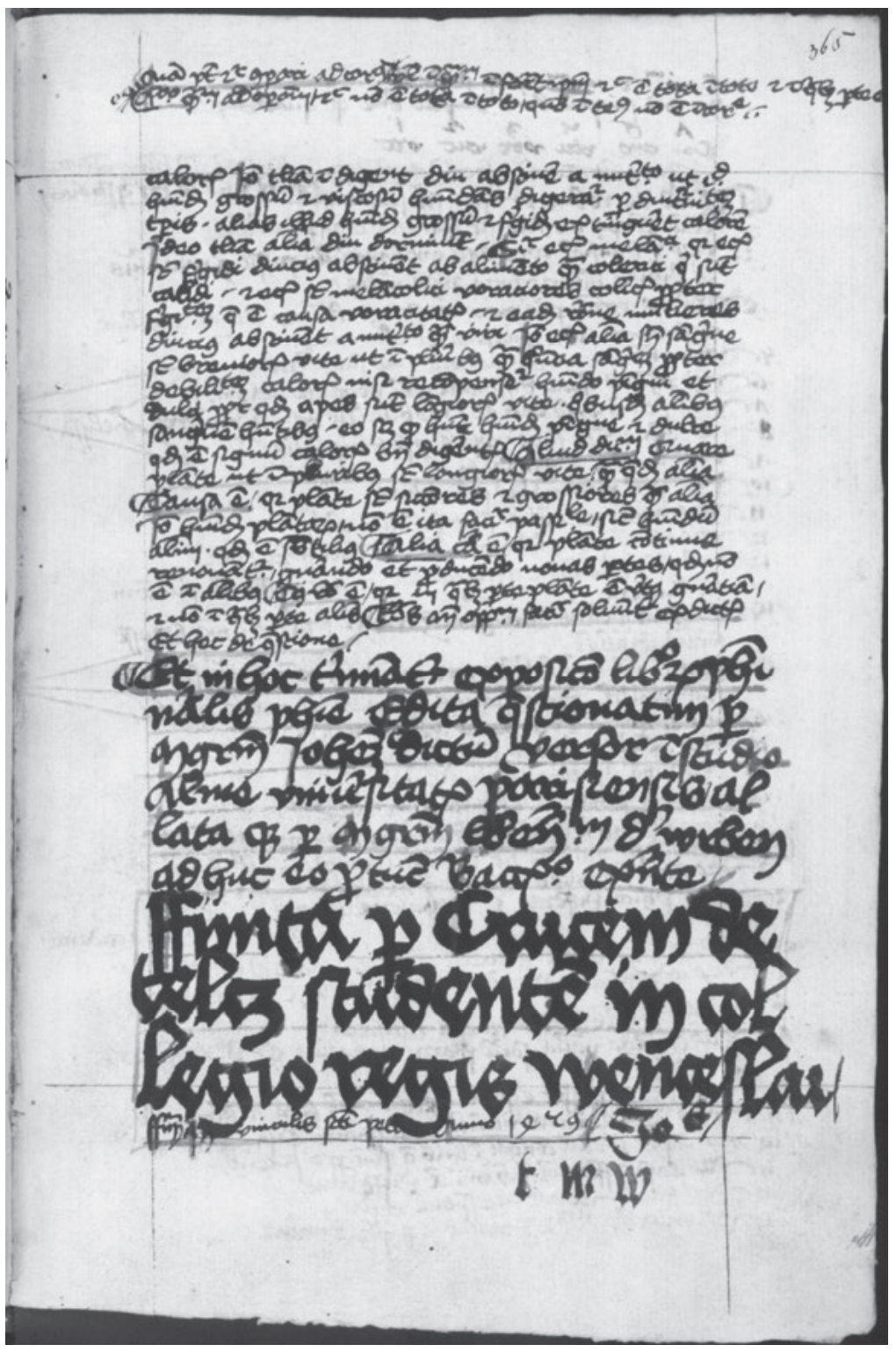

Fig. 7: Prague, NL, I E 38, fol. 365r-final colophon by Crux on finishing copying Jean Versor's commentary on Aristotle brought from Paris University by Václav of Vrbno and copied by Crux while at the college of King Wenceslas in Prague in 1459. 
Crux is not explicitly documented as a student of Charles University, but he did copy several more texts at the King Wenceslas college in 1458 and $1459 .{ }^{28} \mathrm{He}$ also gathered some texts copied there by others, and there are notes on the university and university life in several other manuscripts of his. ${ }^{29}$ Perhaps Crux never actually finished his studies: after all, from 1460, Catholics gradually left the university and from 1462, it was closed to them completely.

Crux also commented on the fact that he sometimes did not copy the texts himself, but bought them or acquired them in some other way. For example, the Sentences in MS Prague, NL, I C 16 were written for Crux by Lawrence of Znojmo (Znaim) in 1465 and only corrected by Crux 'with much effort' ('gravi labore') in 1477 ; $^{30}$ this delay proves, again, Crux was in touch with 'his' manuscripts. The sermons in Prague, NL, I E 37 were partly copied by Crux and partly bought or given to him. He writes:

Ego frater Crux de Telcz conscripsi hos manu propria sermones in seculo existens et quos solus non potui, appreciavi et aliquos sexternos ab aliis habui datos.

I, brother Crux de Telč, copied those sermons with my own hand while I was in the world [i.e. before entering the canonry], and those that I could not [copy] alone I bought, and I was given several sexterns [quires] by others [as well] (fol. 1r).

28 They are in cod. Třeboň, SRA, A 4. Colophons are on fols 61r, 73v, $74 \mathrm{r}$ and 96v.

29 In MS Prague, NL, I G 40, for example, which is an older codex (from 1383) in which Crux only added the table of contents. He may have acquired it in a university environment because it includes notes on Prague University (on fol. 118v: 'studentes pragensis civitatis'). (In addition, it has a unique colophon, first asking to be given a woman called Hanka as a salary for the copying ('Finis adest operis mercedem posco laboris / Non deportabis nisi mihi Hankam dabis. / Explicit Boecius de consolatu philosophie') and then asking the reader not to use the leaves of the book as toilet paper ('Qui te furietur tribus lignis associetur / Si vis merdare stramen tecum debes portare / Si deficit stramen cum naso terge foramen...').

30 'Finitus anno Domini 1465 ... Scriptus per quendam Laurinum de Znoima Prage in Parva parte in pede pontis in domo cruciferorum michi Cruci de Telcz vicario tunc ecclesie s. Pragensis de precio'. ('Finished in the year of our Lord 1465... Written by a certain Lawrence of Znojmo, in Prague in the Lesser Town by the foot of the bridge in the house of the canons regular of the Holy Sepulchre for me, Crux of Telč, at that time a vicar of the holy church in Prague, for a fee'.) And there is a marginal addition as well: 'Ego Crux de Telcz predicator tunc temporis in Sobieslaw a. d. 1477 correxi libros omnes quatuor gravi labore solus in vigilia Mathei apostoli et ewangeliste' ('I, Crux of Telč, at the time a preacher in Soběslav, corrected all four books alone with much effort in the night before [the feast of] Matthew the Apostle and Evangelist, in 1477'; fol. 265r). 
In MS Prague, NL XI C 1, at the end of Bonaventure's Soliloquies copied in Třeboň in 1484, Crux writes that one quire was copied by another brother at the time of Žižka (a famous leader of the Hussite troops) when many left Třeboň and went into exile, only returning later. ${ }^{31}$

Crux had a specific style of handwriting, which varied depending on the size and the speed of writing (Fig. 8). ${ }^{32} \mathrm{He}$ also sketched a number of diagrams. ${ }^{33}$ This does not mean he was a trained illuminator, but since his writing usually overlaps with the drawings (Figs 9 and 10), he is almost certainly the author of the sketches in his own copies. One sophisticated colourful image (MS Prague, NL, I G 11a, fols $17 \mathrm{v}-18 \mathrm{r}$ ) suggests that he was able to draw quite well, in fact.

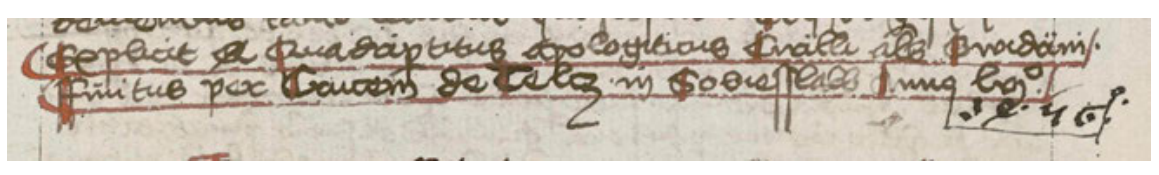

Fig. 8a: Examples of Crux's changing handwriting: 1456 - MS Prague, NL, XIII G 18, fol. 105r.

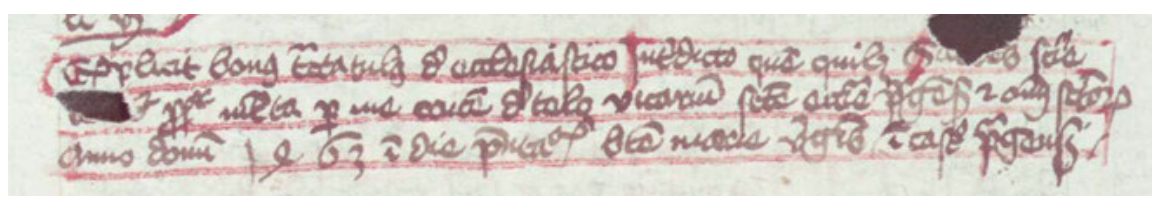

Fig. 8b: 1463 - MS Prague, NL, XI C 8, fol. 178v.

31 'Finitus et suppletus anno domini $M^{\circ}$ CCCC $^{\circ}$ LXXXIIII' feria sexta proxima post Divisionem apostolorum in sillaba illa post. Licet per alium sit totus sexternus quendam fratrem scriptus sicut et alii in exilio quando fuerunt a monasterio Trzebonensi exclusi tempore Zizkonis et postea sunt revocati, hec Crux de Telcz' ('Finished and appended in the year of our Lord 1484 on the nearest Friday after the Dispersion of the Apostles, in the syllable post [16 July 1484]. Although the whole sextern as well as others was written by another brother when they were in exile during the time of Žižka and were called back later, this [was written by] Crux of Telč’; fol. 362v).

32 Pavel Spunar drafted a 'development' of the handwriting, which is, however, not entirely persuasive. He distinguishes four stages: 1454-1460 (horizontal tendency, low and wide letters), 1460-1468 (dense, straight letters), 1468-1470 (curved bases, straight, dense, wide letters), and 1470-1495 (vertical and pointed). Cf. Spunar 1958.

33 E.g. Prague, NL, XI C 1, fols 208v, 212v-213v, 215v, 217r; or Prague, NL, I A 41, fols 176r-199v. 


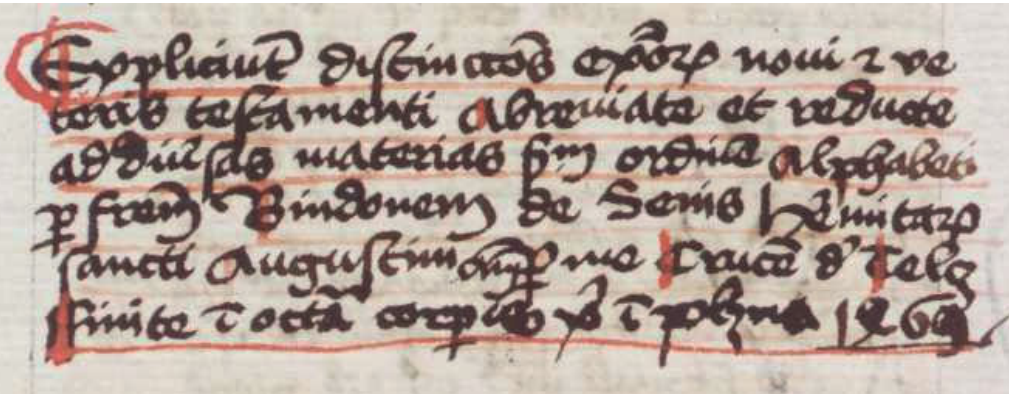

Fig. 8c: 1469 - MS Prague, NL, I A 38, fol. 173r.

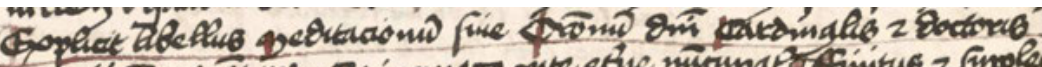

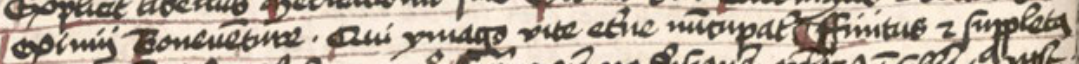

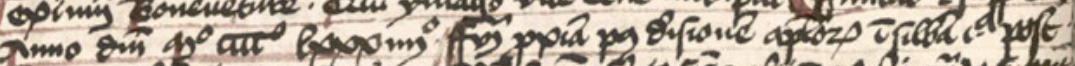

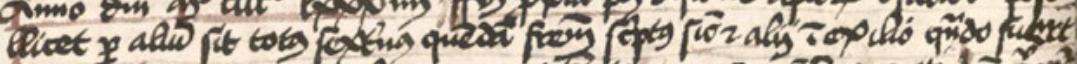

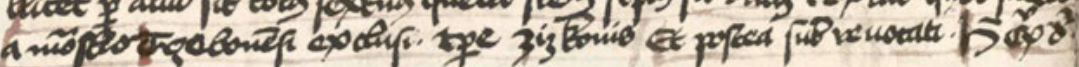

Fig. 8d: 1484 - MS Prague, NL, XI C 1, fol. 361v.

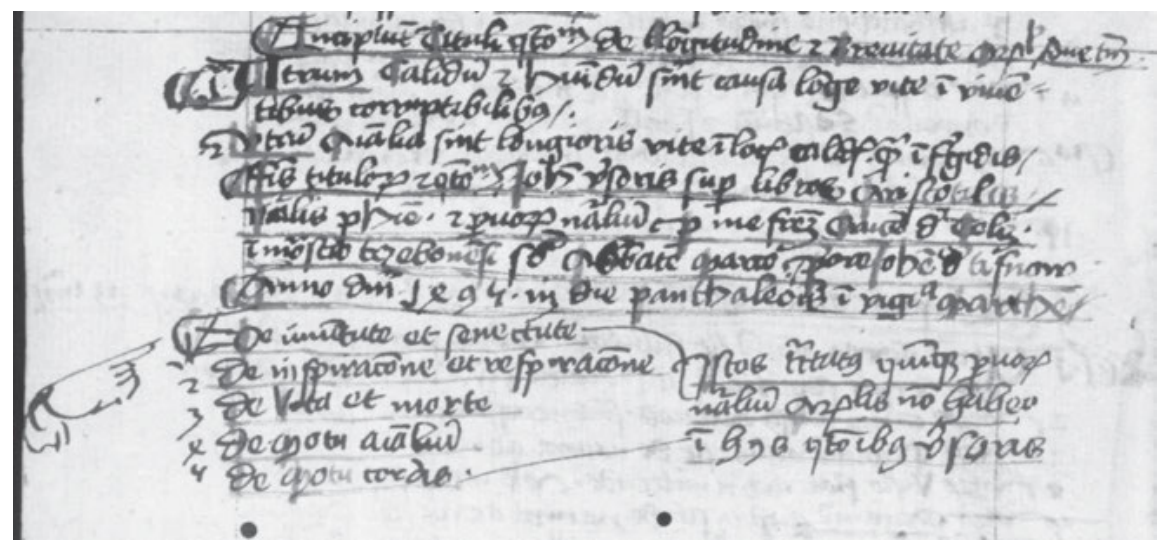

Fig. 8e: 1495-MS Prague, NL, I E 38, fol. 370v. 

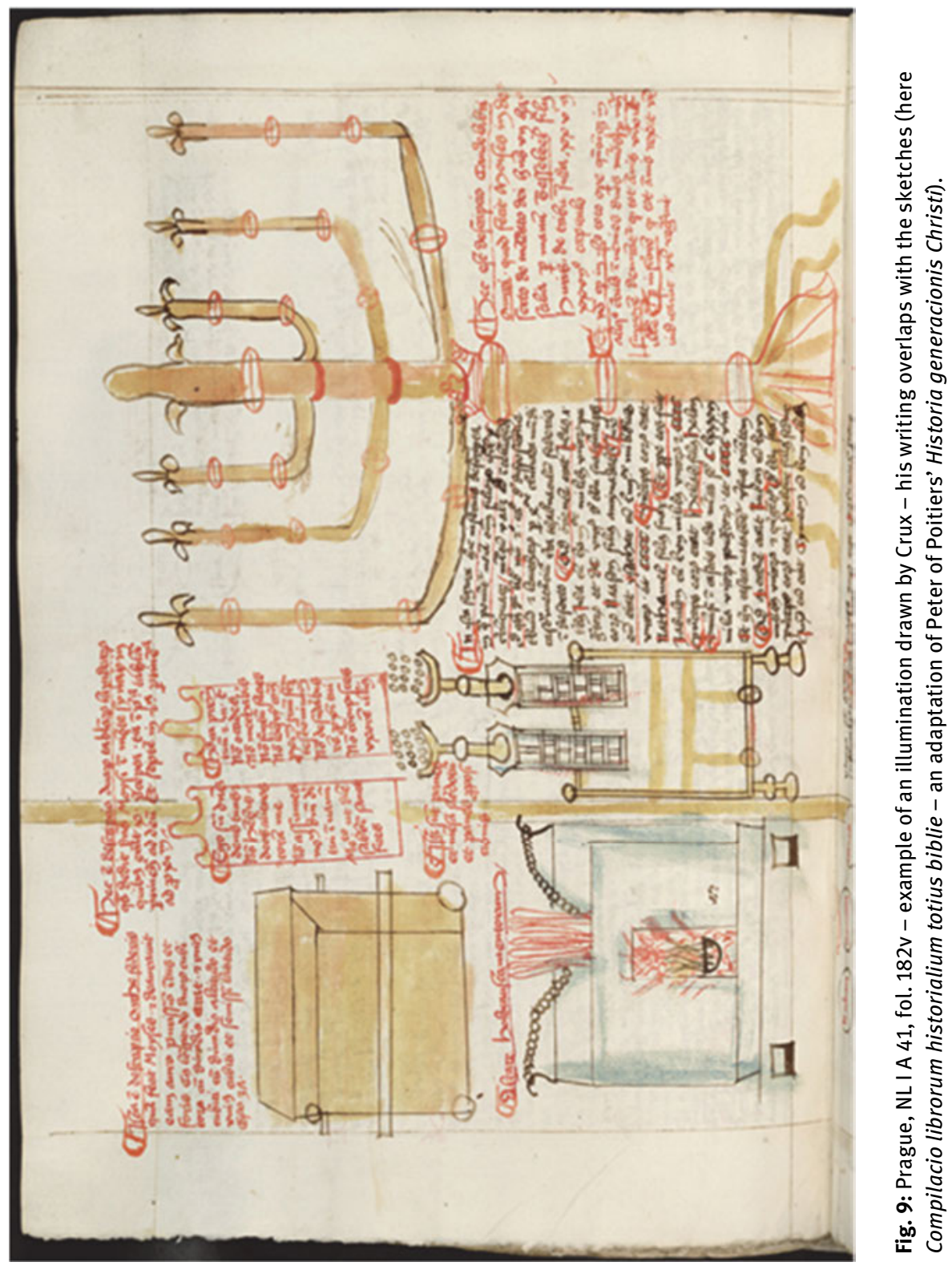


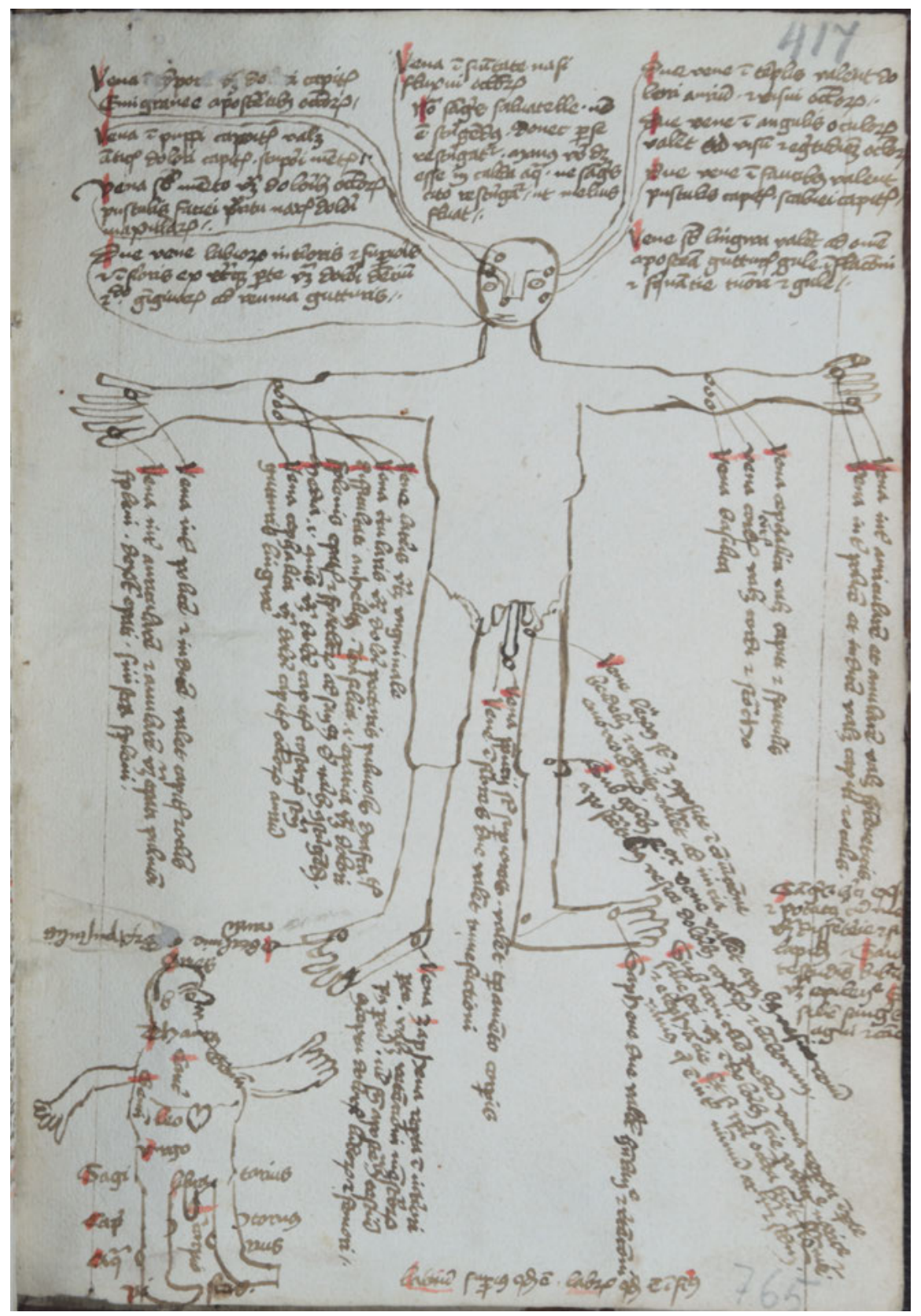

Fig. 10: Třeboň, SRA, A 17 fol. 417r-example of Crux's sketches-here human body with indication of veins for bloodletting. 
Several particular studies have shown that Crux de Telcz was a 'creative' copyist: he added his own notes and comments to the texts that he copied, he only selected particular passages to copy from lengthy works, and he often translated, adapted and even appropriated his models. ${ }^{34}$ This makes cataloguing his codices a true challenge. Very few of Crux's own works have been identified with any certainty yet and none of them is a major or original composition. ${ }^{35}$ Jaroslav Kadlec suggested that Crux may have been the author of several other texts, ${ }^{36}$ but further investigation is necessary to prove or disprove Crux's authorship of these works. In general, his authorship has simply been suggested in cases where the authors of particular texts have not been able to be identified (Crux himself rarely named the authors of the texts he copied) and Kadlec has been proven wrong in several cases of this kind in the past. ${ }^{37}$ The practice of 'creative copying', which is so annoying to cataloguers and editors today, is a practice of appropriation-of making someone else's work one's own-and may be studied in its own right as a reflection of changing preferences, focuses and interests. In fact, it seems to be one of

34 This is not only true of his Latin copies, but of those in Czech as well, such as Old Czech erotic lyric poetry.

35 His only confirmed works are two letters (to Jan Nosidlo, the burgher of Litoměřice, and to Tobias, the headmaster of the school in Tábor, both included in MS Prague, NL, XI C 8) and entries in the Třeboň necrologium from the 1480s (in MS Prague, NL, I G 11c).

36 E.g. the treatise Brevis tractatus de formacione mundi, de creacione angelorum, de situacione et ordinacione mundi et multis aliis bonis (in Třeboň, SRA A6) or polemical comments on the treatise of Jan Rokycana, Contra sex proposiciones frivolas doctorum apostatarum (in MS Prague, National Library I G 11a); cf. Kadlec, 'Oldřich Kř̌̌ž z Telče', 97-98.

37 E.g. when he suggested that Crux had authored a brief epitaph of the canon of Třeboň, Beneš of Strakonice (in MS Prague, NL, XIII G 18), which is actually Epitaphium Senecae (Walther, no. 3960), or a sermon De novo anno (in MS Prague, NL, I E 37, fols 23v-24r), which was probably authored much earlier by Johlín of Vodňany and survives in at least six more earlier manuscripts, and Crux only made minor modifications to it. It was also suggested that he had written the interlinear commentary to Summarium Biblie in MS Prague, I G 11a, which turns out to be part of a complex tradition (Crux may have rewritten the commentary, but he definitely did not author it; cf. Doležalová 2012, 71). It may turn out that this is also true of the notes on Textus Cornuti by Johannes of Garlandia (in MS Prague, NL, XI C 1), the interlinear exposition on the Antigameratus (in MS Prague, NL, XI C 1) and on the Fabula versificata de accipitre et cornice (in MS Prague, NL, I G 11a) - all of which Kadlec also treated as Crux's own creations. In Czech, Crux may have authored Pašije podlé sedmi hodin kněžských rozdělené ('Passion divided according to the seven priestly hours', in MS Prague, NL, I E 37) and the glosses on the Latin New Testament (in MS Prague, NL, I D 18), but in both cases it seems much more likely that Crux merely adapted existing texts. 
the defining characteristics of late medieval manuscript culture, and there are several figures Crux may be compared with in this respect. ${ }^{38}$

Browsing through Crux's MTMs, one is puzzled and rather overwhelmed; their miscellaneity is indeed striking at times. MS Prague, XI C 8, for example, one of the two volumes almost fully copied by Crux, has a brief ad hoc table of contents in the lower right-hand corner of the inside front cover listing 15 items. Yet it only cites the longer pieces, whereas the codex actually contains over 140 different texts (on 306 folios) on various topics, some long, others very brief. It particularly includes moral, devotional and theological texts, but it also features an apocryphal life of Adam and Eve, an exorcism, synodal statutes, religious polemic and even satirical songs. It is not clear what led Crux to copy the texts in this order-it may just have been a random selection, in fact. There are sections that are thematically related, e.g. a number of contemporary texts related to the polemics on communion on fols $183 \mathrm{r}-200 \mathrm{v}-$ a section which then dissolves into a variety of brief opuscles of mixed authority and character. Crux's own letter to Jan Nosidlo, the burgher of Litoměřice, probably from early 1463 is also included here along with his typical signature-the image of a cross standing for his name (crux means 'cross' in Latin) (Fig. 11).

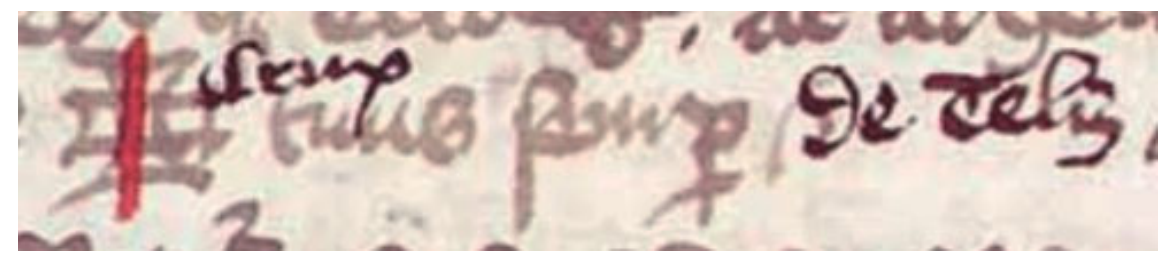

Fig. 11: Prague, NL, XI C 8, fol. 281r-example of Crux's signature-'Crux tuus semper de Telcz' ('your Crux / cross forever of Telč').

It seems impossible to grasp the character of these complex MTMs in a catalogue's description: several of the entries in the catalogue of Crux's miscellanies ${ }^{39}$ are over 40 pages long and thus do not allow the reader to see the composition, layers, scribal interventions and the possible logic behind the codex as a whole very clearly. Crux's own tables of contents provide a useful hint about how he

38 Other late medieval 'creative copyists' include the Benedictine monk Gallus Kemli from St Gall (cf. Doležalová 2013), the Augustinian canon from Sagan, Andreas Ritter (cf. Honemann 2006) and the Augustinian canon of Roudnice nad Labem, Mattheus Beran (cf. Doležalová 2018). 39 Currently being prepared by Lucie Doležalová, Michal Dragoun and Adéla Ebersonová. 
approached and used the volumes, where he saw the beginning of new thematic units, and what was crucial for him in terms of the codex's contents. These tables together with his glosses and internal references show that although the codices may seem clumsy, unsystematic and user-unfriendly to us today, they were used and found useful at the time.

$$
* * *
$$

Although this case study is far from finished, Crux's example shows us the way in which the late medieval boom in information and spread of knowledge was managed: scribes took over the role of authors, not hesitating to adjust their models to their momentary aims, and association became the primary organisational principle. The resulting MTMs mark an important point of transition in the practice of dissemination of knowledge and can be used to analyse late medieval cultural and intellectual milieu. ${ }^{40}$

Due to the large number of texts he copied and compiled, Crux still seems rather exceptional within this context-a tireless busybody interested in any text on any subject. He was clearly not simply a graphomaniac; he would not only copy texts, but read and re-read them, comment upon them, and correct and translate them. A detailed analysis of his codices compared with the composition of the medieval library of the Třeboň canonry (where he spent the last 26 years of his life) will allow us to analyse the nature of his 'creative copying' (that is, what types of changes he made to his models, and, hopefully, for what reasons) as well as his selection and ordering principles. Did Crux just copy everything or did he choose what to copy? What was he primarily interested in? Does his ordering of the texts reveal anything about his mental map, associative links, education and opinions? The case is curious on a more general level, too: the avid hand copying, personalising and appropriating the texts in such a massive degree is a swan song at the wake of print culture, which would eventually confine similar efforts to the limited category of personal notebooks and change the nature of textual transmission altogether.

40 For a comparison-information management in early-modern print culture-see Blair 2010. 


\section{Appendix: Crux's colophons from MS Prague, NL, I E 38}

28.4. $83 r$

1.5. $95 r$

9.5. $119 r$

12.5. $141 \mathrm{r}$

31.5. $194 \mathrm{v}$

11.6. $227 v$

19.6. $246 \mathrm{v}$

23.6. $264 \mathrm{r}$

23.6. $263 r$

26.6. 269 bis $r$

17.7. $313 \mathrm{v}$

21.7. $333 r$

26.7. $350 v$

28.7. $355 r$

1.8. $365 r$
Et sic est finis libri quarti Phisicorum sabbato ante dominicam Rogacionum in collegio regis Wenceslai anno $\mathrm{M}^{\circ} \mathrm{CCCC}^{\circ} \mathrm{LIX}^{\circ}$.

Et est finitum in die Philipi et lacobi anno eodem in collegio regis Wenceslai Prage.

Et hec de toto septimo Phisicorum feria IIII ante Penthecosten.

Finiti sunt sabbato in vigilia Penthecosten in collegio regis Wenceslai Prage anno Domini $\mathrm{M}^{\circ} \mathrm{CCCC}^{\circ} \mathrm{LIX}^{\circ}$.

Et hec de questione et per consequens de toto libro celi et mundi terminato feria quinta in octava Corporis anno 1459 Prage in collegio regis Wenceslai.

Et hec de questione et per consequens de toto secundo libro De generacione feria secunda ante Viti anno 1459.

Et hec de primo Metheorum in die sancti Prothasii feria quarta. ${ }^{41}$

Et hec de secundo Metheorum sabbato in vigilia Iohannis Baptiste.

Finitum sabbato in vigilia lohannis Baptiste hora $23^{\mathrm{a}}$.

Et hec de primo De anima, in die sancti Iohannis et Pauli.

Et hec de questione et per consequens de toto secundo De anima, in die sancti Allexii Prage.

Et hec de anima dicta sufficiant et per consequens de toto De anima Aristotelis anno $1459^{\circ}$, anno secundo regni Bohemie regis Georgii finitum Prage per Crucem de Telcz in collegio regis Wenceslai sabbato ante Marie Magdalene hora $22^{\mathrm{a}}$.

Et hec de questione et per consequens de toto libro De sensu et sensato feria quinta post lacobi in die sancte Anne matris Marie.

Et hec de toto libro De memoria et reminiscencia sabbato post lacobi anno $1459^{\circ}$ Prage in collegio regis Wenceslai.

Et in hoc terminatur exposicio librorum Philosophi naturalis philosophie edita questionatim per magistrum lohannem dictum Versor in studio alme universitatis Parisiensis allataque per magistrum Wenceslaum de Wrben adhuc eo pro tunc baccalario existente, finita per Crucem de Telcz studentem in collegio regis Wenceslai feria quarta in vinculis sancti Petri anno 1459.

41 It should say tercia here to match the saint's day. 


\section{Manuscripts}

\section{Prague, National Library of the Czech Republic}

$\begin{array}{ll}\text { IA } 38 & \text { IF } 25 \\ \text { IA } 41 & \text { IF } 35 \\ \text { IB } 28 & \text { I G 11a } \\ \text { IB } 33 & \text { I G 11c } \\ \text { IC } 16 & \text { XI C } 1 \\ \text { I D } 18 & \text { I G 40 } \\ \text { IE } 37 & \text { XI C } 8 \\ \text { IE } 38 & \text { XIII G 18 } \\ \text { IE 42 } & \text { Adlig. 44 D 4 } \\ \text { IF } 18 & \end{array}$

\section{Třeboň, State Regional Archives}

\section{References}

Blair, Ann M. (2010), Too Much to Know: Managing Scholarly Information before the Modern Age. New Haven, CT: Yale University Press.

Coufal, Dušan (2015), 'Interrogatorium kostnického koncilu proti wyclifitům. Analýza a edice textu' [Interrogatorium of the Council of Constance against Wycliffites. Analysis and Text Edition], in Časopis Matice moravské, 134: 3-28.

Doležalová, Lucie (2012), Obscurity and Memory in Late Medieval Manuscript Culture: The Case of the 'Summarium Biblie'. Krems: Institut für Realienkunde des Mittelalters und der frühen Neuzeit.

Doležalová, Lucie (2013), 'Multiple Copying and the Interpretability of Codex Contents: “Memory Miscellanies” Compiled by Gallus Kemli (1417-1480/1) of Sankt Gallen', in Lucie Doležalová / Kimberly Rivers (eds), Medieval Manuscript Miscellanies: Composition, Authorship, Use. Krems: Institut für Realienkunde des Mittelalters und der frühen Neuzeit.

Doležalová, Lucie (2018), 'Late Medieval Personal Miscellanies: The Case of Mattheus Beran (d. 1461), Augustinian Canon of Roudnice nad Labem', in Sabrina Corbellini / Giovanna Murano / Giacomo Signore (eds), Collecting, Organizing and Transmitting Knowledge. Miscellanies in Late Medieval Europe (Bibliologia. Elementa ad librorum studia pertinentia 49), Turnhout: Brepols, 179-96. 
Dragoun, Michal/ Ebersonová, Adéla (2015), 'Soupis roudnických a sadských rukopisů’ [Catalogue of manuscripts from Roudnice and Sadská], in Lucie Doležalová / Michal Dragoun / Adéla Ebersonová (eds), Ubi est finis huius libri deus scit. Středověká knihovna augustiniánských kanovníků v Roudnici nad Labem [Ubi est finis huius libri deus scit. Medieval Library of Augustinian Canons in Roudnice nad Labem]. Prague: Scriptorium, 498-502.

Ebersonová, Adéla / Klima, Alice (2015), Roudnická statuta [The statutes of Roudnice], in Ubi est finis huius libri deus scit. Středověká knihovna augustiniánských kanovníků v Roudnici nad Labem, Prague: Scriptorium, 2015, 187-205.

Ebersonová, Adéla (2019) Roudnická statuta. Zvyklosti kanonie řeholních kanovníků sv. Augustina $v$ Roudnici nad Labem (komentovaná edice a preklad) [The statutes of Roudnice. The Consuetudines of the regular conanons of the Augustinian canonry in Roudnice nad Labem - commented edition and translation], Prague: Scriptorium (in print).

Honemann, Volker (2006), 'Zu Leben und Werk des Saganer Augustinerchorherren Andreas Ritter', in Ralf G. Päsler / Dietrich Schmidtke (eds), Deutschsprachige Literatur des Mittelalters im östlichen Europa. Heidelberg: Winter Verlag.

Kadlec, Jaroslav (1956), 'Oldřich Křǐž z Telče’ [Ulrich Crux de Telcz], in Listy filologické, 79, 1: 91102 and 79/2: 234-38.

Kadlec, Jaroslav (2004), Klášter augustiniánských kanovníků v Třeboni [The monastery of Augustinian canons in Třeboň]. Prague: Karolinum.

Kiss, Farkas Gábor (2012), 'Performing from Memory and Experiencing the Senses in Late Medieval Meditative Practice: The Treatises Memoria fecunda, Nota hanc figuram and Alphabetum Trinitatis', in Daphnis, 41: 419-52.

Kopecký, Milan (ed.) (1983), Zbav mě mé tesknosti [Free Me from My Grief]. Brno: Blok.

Lehár, Jan (ed.) (1990), Česká středověká lyrika [Czech Medieval Lyrical Poetry]. Prague: Vyšehrad.

Mareš, František (1896), Literární působení kláštera třeboňského [Literary impact of the Třeboň canonry], in Časopis Musea království Českého, 70: 521-47.

Šmahel, František (2016), 'Johannes Versor a jeho češti žáci', in Alma mater Pragensis: Studie k počátkům university Karlovy. Prague: Karolinum, 459-75 [German version: Šmahel, František (2016), 'Paris und Prag um 1450: Johannes Versor und seine böhmischen Schüler', in Studia źródtoznawcze, 25, 65-77].

Spunar, Pavel (1958), 'Vývoj autografu Oldřicha Křǐže z Telče. Př̌spěvek k poznání písařské osobnosti ve středověku' [The development of the autograph of Ulrich Crux de Telcz. Contribution to understanding a scribal personality in the Middle Ages], in Listy filologické, 81, 6, 2: 220-26.

Truhlár̆, Josef (1905-1906), Catalogus codicum manu scriptorum latinorum qui in bibliotheca C.R. Bibliotheca publica atque Universitatis Pragensis asservantur, I-II. Prague: Královská akademie věd.

Walther, Hans (1959), Initia carminum ac versuum Medii Aevi posterioris Latinorum, Göttingen: Vandenhoeck \& Ruprecht.

Weber [Kadlec], Jaroslav (1958), 'Catalogus codicum manu scriptorum archivii Trzebonensis', in Catalogus codicum manu scriptorum Trzebonae Crumloviique asservatorum. Prague: Královská akademie věd. 